\title{
Erratum to: Model for Strain-Induced Precipitation Kinetics in Microalloyed Steels
}

\author{
SEBASTIAN F. MEDINA, ALBERTO QUISPE, and MANUEL GOMEZ
}

DOI: $10.1007 / \mathrm{s} 11661-014-2297-\mathrm{y}$

(C) The Minerals, Metals \& Materials Society and ASM International 2014

Erratum to: METALLURGICAL AND MATERIALS

TRANSACTIONS A, Vol. 45A, No. 3,

March 2014, pp. 1524-1539

DOI 10.1007/s11661-013-2068-1

ON page 1534, first column, last paragraph, the correct sentence is as follows:

In the case of V-steels, $X_{\mathrm{i}}$ is $(\mathrm{V}$ pct $)(\mathrm{N}$ pct $) \cdot 10^{3}$ and in the case of Nb-steels it should be (pct Nb)(pct C) $)^{0.7}$ (pct $\mathrm{N})^{0.2} \cdot 10^{3}$.

The online version of the original article can be found under doi: 10.1007/s11661-013-2068-1.

Article published online April 3, 2014 